Western North American Naturalist 70(1), (C) 2010, pp. 117-120

\title{
PREDATION OF ADULT RAZORBACK SUCKER AND BONYTAIL BY STRIPED BASS IN LAKE MOHAVE, ARIZONA-NEVADA
}

\author{
Abraham P. Karam ${ }^{1,2}$ and Paul C. Marsh ${ }^{1}$
}

\begin{abstract}
We report 2 separate records from sport-fish anglers in Lake Mohave, Arizona-Nevada, that document the presence of endangered razorback sucker Xyrauchen texanus and bonytail Gila elegans in stomach contents of large $(13+\mathrm{kg})$ nonnative striped bass Morone saxatilis. These records suggest that striped bass, since their first appearance in Lake Mohave nearly 3 decades ago, may have played a role in population declines of the other 2 species. Current native-fish stocking programs at Lake Mohave continue to face significant obstacles to achieving population recoveries because all life stages of repatriated individuals, including mature adults, are vulnerable to predation.
\end{abstract}

Key words: razorback sucker, bonytail, predation, nonnative fish, striped bass, Colorado River.

Lake Mohave, Arizona-Nevada, is a mainstem lower Colorado River reservoir that serves as critical habitat for endangered razorback sucker Xyrauchen texanus and bonytail Gila elegans (U.S. Fish and Wildlife Service 1994). Since the reservoir was enclosed in 1951, no recruitment by either species has been documented (Mueller 2006), and their continued existence is linked to stocking programs (Mueller and Marsh 2002, Marsh et al. 2003). Early stocking endeavors released hundreds of thousands of juvenile fish into the reservoir (Minckley and Thorson 2007, Schooley and Marsh 2007), but those efforts were not successful at stabilizing or reversing population declines resulting from predation by nonnative fish (Marsh and Brooks 1989, Johnson et al. 1993, Marsh and Pacey 2005).

Striped bass Morone saxatilis first appeared in Lake Mohave in 1981, and numbers surged after 1983, when excess water was released from Lake Mead via the spillway tunnels on Hoover Dam (Minckley and Marsh 2009). Over 3 decades, the reservoir developed into a fishery for trophy striped bass, producing individuals in excess of $25 \mathrm{~kg}$. Striped bass have been implicated in declines of native fish in Lake Mohave, particularly of repatriated razorback sucker (Karam et al. 2008). Because of predation concerns, size-at-release of stocked fish has been incrementally increased in attempts to bolster populations (Marsh et al. 2005).
In order to determine whether size-at-release affects poststocking survival, a multiyear acoustic telemetry study was implemented in 2006 using subadult and adult razorback sucker repatriates. Groups of razorback sucker were implanted with acoustic transmitters, released into Lake Mohave, and telemetered using passive and active tracking techniques. Transmitters that became immobile were inspected and recovered using scuba and an underwater receiver (for a complete review, see Karam et al. 2008).

Concurrently, sport-fish anglers were informed of ongoing research activities and were asked to participate by reporting stomach contents of large striped bass. A series of outreach signs were posted around the reservoir and on internet fishing forums. Also, a collaborative effort was undertaken with Nevada Division of Wildlife creel clerks to document native fish predation events.

Two instances of predation by striped bass on large repatriates of native fish were reported. The first was on 12 November 2008, when an angler harvested a 13.6-kg striped bass near Liberty Cove (Fig. 1). Upon cleaning his catch, the angler reported finding an acoustic transmitter in the stomach of the striped bass. This striped bass was caught approximately $4 \mathrm{~km}$ downriver from Fortune Cove, where a small group of transmitter-tagged subadult (average total length $[\mathrm{TL}]=38 \mathrm{~cm}$ ) and adult (average $\mathrm{TL}=54 \mathrm{~cm}$ ) razorback suckers were released

${ }^{1}$ Native Fish Lab, Marsh \& Associates, LLC, 5016 South Ash Avenue, Suite 108, Tempe, AZ 85282

${ }^{2}$ E-mail: abraham.karam@gmail.com 


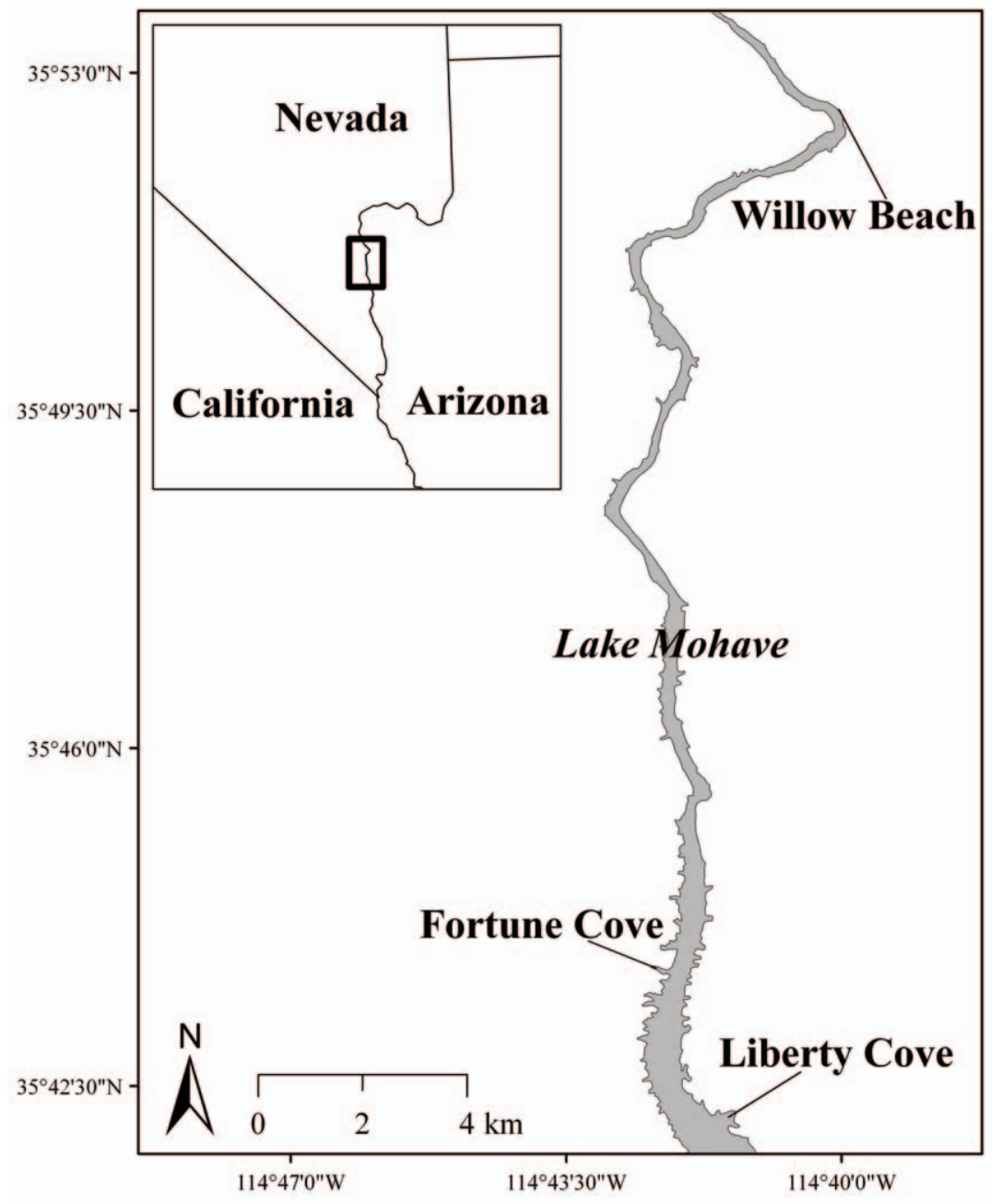

Fig. 1. Map of Lake Mohave, Arizona-Nevada showing (1) stocking locations for razorback sucker (Fortune Cove) and bonytail (Willow Beach) and (2) locations where anglers harvested striped bass containing razorback sucker (Liberty Cove) and bonytail (Willow Beach).

on 6 November 2008 (Fig. 1). The transmitter had been implanted in a male adult repatriate $(50 \mathrm{~cm} \mathrm{TL}, 1.3 \mathrm{~kg})$ that was telemetered a maximum distance of $5 \mathrm{~km}$ from the release site over a 6 -day poststocking period before contact with the fish was lost.

Information regarding the second episode was obtained during an interview on 21 March 2009 at the Willow Beach, Arizona, fish-cleaning station. There an angler reported that during late 2007 he harvested a striped bass $(>13 \mathrm{~kg}$ ) within $1.6 \mathrm{~km}$ of Willow Beach (Fig. 1) that contained numerous razorback sucker in its stomach. Supporting photographs (datestamped 18 December 2007) provided by the angler revealed that the fish removed from the stomach of the striped bass were actually bonytail (Fig. 2). While the origin of those fish is not known, it is highly probable that they originated from a large-batch stocking of bonytail $(n=1636$, average TL $=25 \mathrm{~cm})$ at Willow Beach National Fish Hatchery on 13 December 2007.

These observations are important for 2 reasons. In the case of razorback sucker, questions remained as to whether adult repatriates of the current recommended stocking size $(\geq 50 \mathrm{~cm}$ TL) are immune to predation by striped bass, which is the only piscivore in the reservoir with a gape large enough to ingest fish of that 


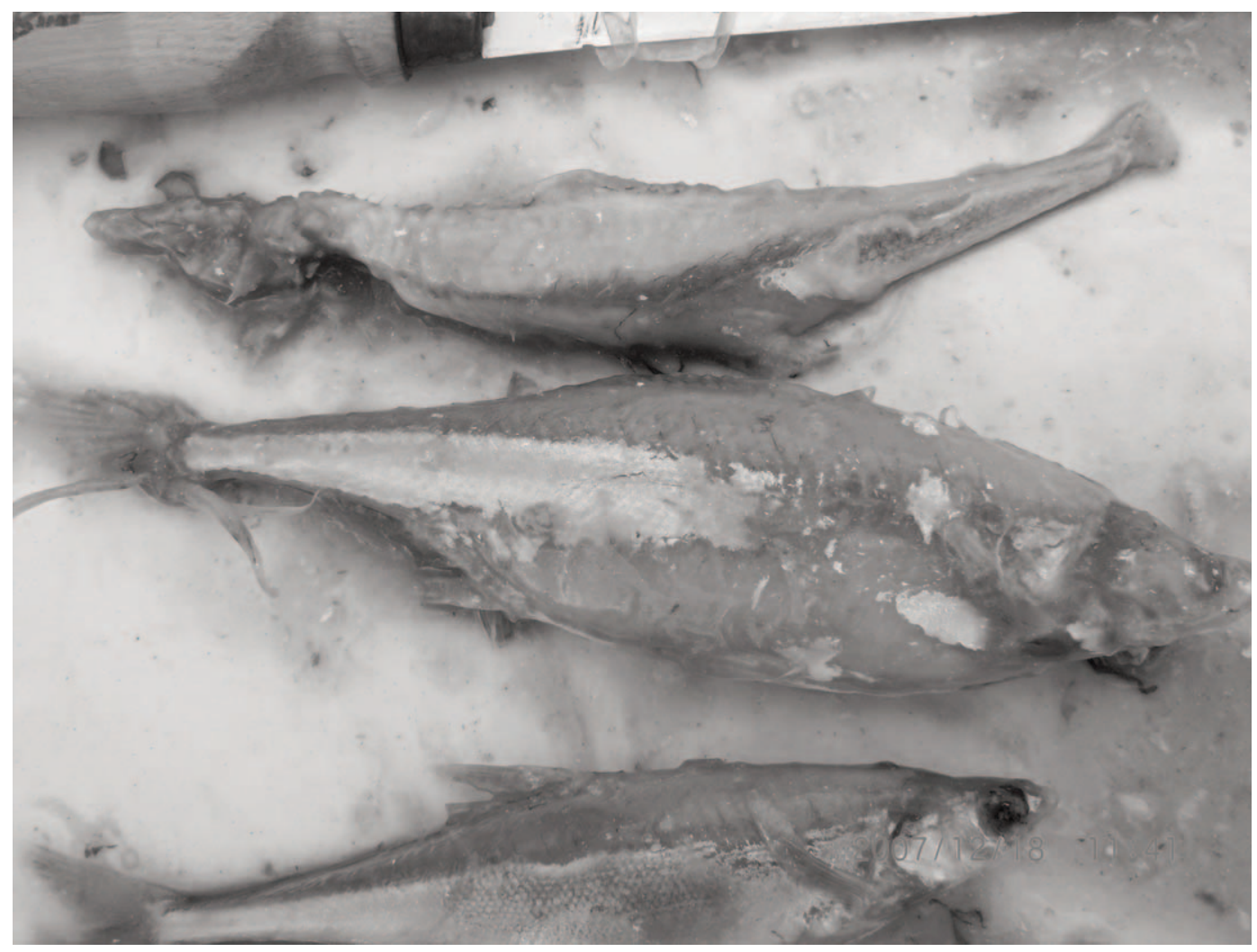

Fig. 2. Photograph taken on 18 December 2007 depicting 3 bonytail removed from the stomach of a striped bass $(>13 \mathrm{~kg})$ harvested within $1.6 \mathrm{~km}$ of Willow Beach, Arizona.

size (Dennerline and Van Den Avyle 2000). The observation of predation implies that these fish are vulnerable. Survival of adult razorback sucker is difficult to quantify without the benefit of several years of releases and corresponding mark-recapture data, but it should be noted that even the largest razorback sucker repatriates currently being released into Lake Mohave are vulnerable to predation by large striped bass.

As for bonytail, 23,770 subadult and adult PIT-tagged hatchery individuals have been repatriated into the reservoir since 1995 . Since then, only 8 repatriates have been recaptured, the last of which occurred in 2005. A large striped bass which had consumed multiple bonytail was caught in the vicinity of a recent batch stocking, indicating that bonytail are also susceptible to striped bass predation.

The Lake Mohave striped bass fishery may be hindering native-fish recovery efforts. Although it is well documented that early life stages of native fish are vulnerable to predation (Marsh and Langhorst 1988, Mueller and Marsh 2002), it also appears that striped bass feed on some of the largest repatriates that are currently stocked into the reservoir. In order to reach recovery goals, substantial efforts should be made to create and manage additional offchannel backwater habitats that are free of piscivorous nonnative fish (Minckley et al. 2003, Mueller 2006).

We thank T. Stephens of the Nevada Division of Wildlife, T. Burke of the U.S. Bureau of Reclamation, B. Kesner and C. Pacey of Marsh \& Associates, LLC, and 2 anonymous anglers for their participation. Funding for this study was provided by the U.S. Bureau of Reclamation.

\section{Literature Cited}

Dennerline, D.E., and M.J. Van Den Avyle. 2000. Sizes of prey consumed by two pelagic predators in US 
reservoirs: implications for quantifying biomass of available prey. Fisheries Research 45:147-154.

Johnson, J.E., M.G. Pardew, and M.M. Lyttle. 1993. Predator recognition and avoidance by larval razorback sucker and northern hog sucker. Transactions of the American Fisheries Society 122:1139-1145.

Karam, A.P., B.R. Kesner, and P.C. Marsh. 2008. Acoustic telemetry to assess post-stocking dispersal and mortality of razorback sucker Xyrauchen texanus. Journal of Fish Biology 73:719-727.

MarSh, P.C., AND J.E. BROOKS. 1989. Predation by ictalurid catfishes as a deterrent to re-establishment of hatchery-reared razorback suckers. Southwestern Naturalist 34:188-195.

Marsh P.C., B.R. Kesner, and C.A. PaCEy. 2005. Repatriation as a management strategy to conserve a critically imperiled fish species. North American Journal of Fisheries Management 25:547-556.

Marsh, P.C., AND D.R. Langhorst. 1988. Feeding and fate of wild larval razorback sucker. Environmental Biology of Fishes 21:59-67.

Marsh, P.C., AND C.A. PACEY. 2005. Immiscibility of native and nonnative fishes. Pages 59-63 in Restoring native fish to the lower Colorado River: interactions of native and nonnative fishes. U.S. Fish and Wildlife Service, Albuquerque, NM, and U.S. Bureau of Reclamation, Boulder City, NV.

Marsh P.C., C.A. Pacey, and B.R. Kesner. 2003. Decline of the razorback sucker in Lake Mohave, Colorado River, Arizona and Nevada. Transactions of the American Fisheries Society 132:1251-1256.

Minckley, C.O., AND M.S. Thorson. 2007. A review of the distribution and management of bonytail in the lower
Colorado River Basin. American Fisheries Society Symposium 53:129-134.

MincKLEY, W.L., AND P.C. Marsh. 2009. Inland fishes of the greater Southwest: chronicle of a vanishing biota. University of Arizona Press, Tucson, AZ.

Minckley, W.L., P.C. Marsh, J.E. Deacon, T.E. Dowling, P.W. Hedrick, W.J. Matthews, and G. Mueller. 2003. A conservation plan for native fishes of the lower Colorado River. BioScience 53:219-234.

Mueller, G.A. 2006. Ecology of bonytail and razorback sucker and the role of off-channel habitats in their recovery. U.S. Geological Survey Scientific Investigations Report 2006-5065. 64 pp.

Mueller, G.A., AND P.C. Marsh. 2002. Lost, a desert river and its native fishes: a historical perspective of the lower Colorado River. Information and Technology Report USBS/BRD/ITR-2002-0010, U.S. Government Printing Office, Denver, CO. 69 pp.

Schooley, J.D., AND P.C. Marsh. 2007. Stocking of endangered razorback sucker in the lower Colorado River basin over three decades: 1974-2004. North American Journal of Fisheries Management 27:43-51.

U.S. Fish and WiLdlife Service. 1994. Endangered and threatened wildlife and plants; determination of critical habitat for the Colorado River endangered fishes: razorback sucker, Colorado squawfish, humpback chub, and bonytail chub. Federal Register 59: 13374-13400.

Received 18 May 2009

Accepted 6 October 2009 